\title{
Dental care utilization among children in Brazil: an exploratory study based on data from national household surveys
}

\author{
Utilização de serviços odontológicos entre crianças no Brasil: \\ estudo exploratório a partir das pesquisas nacionais \\ por amostra de domicílios
}

Jéssica Copetti Barasuol ${ }^{1}$
Leila Posenato Garcia $^{2}$
Rafaella Coelho Freitas $^{3}$
Debora Martini Dalpian
José Vitor Nogara Borges Menezes $^{4}$
Bianca Zimmermann Santos
${ }^{1}$ Centro de Ciências da Saúde, Universidade Federal de Santa Catarina. R. Eng. Agronômico Andrei Cristian Ferreira $s / n$, Trindade. 88040-900 Florianópolis SC Brasil. jessica.barasuol@ hotmail.com

${ }^{2}$ Diretoria de Estudos Setoriais, Instituto de Pesquisa Econômica Aplicada. Brasília DF Brasil.

${ }^{3}$ Universidade Franciscana. Santa Maria RS Brasil.

${ }^{4}$ Universidade Federal do

Paraná. Curitiba PR Brasil.

\begin{abstract}
Wide availability of access to dental services can be considered a predictor of better oral health outcomes in a population. This article aims to compare data from the Brazilian National Household Sample Surveys (PNAD) on dental services utilization among children aged 4 to 12 years. This cross-sectional study was carried out using data from the 1998, 2003, and 2008 National Household Sample Surveys, involving a total of 61.438, 64.659 and 59.561 children, respectively. Ninety-nine percent confidence intervals were considered for the prevalence of each outcome of interest. In 1998, 60.8\% (99\%CI: 59.4;62.1) of children had been to a dentist; this prevalence was 65.5\% (99\%CI: 64.4;66.7) in 2003 and 73.8\% (99\%CI: $72.1 ; 74.2)$ in 2008. In 1998, 41.2\% (99\%CI: 39.1;43.3) of children in the lowest household income quartile had been to a dentist; this value was $61.4 \%$ (99\% CI: 59.5;63.2) in 2008. Among children from families whose head of household had 4 years of formal education or fewer, $49.5 \%$ and $63 \%$ had been to a dentist in 1998 and 2008, respectively. The lifetime prevalence of dentist attendance among Brazilian children increased between 1998 and 2008, especially among those from low-income families and those whose head of household had a low educational level. Key words Inequality, Access to health care
\end{abstract}

Resumo A ampla disponibilidade de acesso aos serviços odontológicos pode ser considerada um fator preditor de melhores resultados na saúde bucal da população. O objetivo deste artigo é comparar os dados obtidos das Pesquisas Nacionais por Amostras de Domicílios (PNADs), em relação a utilização de serviços odontológicos, entre crianças de 4 a 12 anos. Estudo transversal, com dados obtidos a partir das PNADs realizadas em 1998, 2003 e 2008, envolvendo um total de 61.438, 64.659 e 59.561 crianças, respectivamente. Considerou-se intervalos de confiança de $99 \%$ para os desfechos. No ano de 1998, 60,8\% (IC99\%: 59,4;62,1) das crianças haviam ido ao dentista, em 2003, 65,5\% (IC99\%: 64,4;66,7), e em 2008, 73,8\% (IC99\%: 72,1;74,2). Com relação à renda domiciliar, em 1998, 41,2\% (IC99\%: 39,1;43,3) das crianças inseridas nas famílias na menor faixa de renda foram ao cirurgião-dentista, em 2003 49,9\% (IC99\%: 48;51,9) o fizeram e, em 2008, 61,4\% (IC99\%: 59,5;63,2). Entre as que pertenciam a famílias onde o chefe possuía até 4 anos de estudo, 49,5\% e 63\%, em 1998 e 2008, foram às consultas odontológicas. A prevalência de crianças brasileiras que já haviam ido ao dentista aumentou entre 1998 e 2008, especialmente entre aquelas pertencentes a famílias com renda domiciliar menor e com chefes possuindo menor escolaridade.

Palavras-chave Iniquidade social, Acesso aos serviços de saúde 


\section{Introduction}

Access to health care services has population-wide impacts on oral health. Quantitative and qualitative research is essential on assessing the effectiveness of such services. Access to oral health services specifically is characterized by entry into the public or private health systems. It is dependent on a wide range of individual and collective characteristics, such as socioeconomic conditions, demographic profile, need for care, self-perceived oral health, and, in the pediatric population, parents' understanding of their children's oral health needs ${ }^{1,2}$.

According to the 1988 Brazilian Constitution o, universal access to public health services for all citizens is a duty of the state and one of the guiding principles of the Brazilian Unified Health System (SUS). Access has been improving progressively through planning and increased availability of material, human and financial resources; however, in certain regions of the country, it is still limited, particularly for people of lower socioeconomic status ${ }^{3-6}$.

According to the 2010 National Oral Health Survey, approximately $18 \%$ of 12 -year-old children in Brazil had never been to a dentist. The worst results were found in the North and Northeast regions of the country, which have a lower Human Development Index (HDI) compared with other regions ${ }^{7,8}$. The Oral Health Brasil (SB Brasil) project demonstrated a difference in the $\mathrm{dmf}$ index (primary teeth decayed, filled, or with indications for extraction) across regions, with a higher prevalence of caries in the North and Northeast regions, and the prevalence of filled teeth being higher in the Southeast and South ${ }^{7}$. According to the 2013 National Health Survey, $45.2 \%$ of the pediatric population (aged 0 to 17 years) had sought dental care in the preceding 12 months?.

Despite progress in the core principles of comprehensiveness and universality, the SUS still fails to provide an appropriate response and structure to address the oral health issues that affect part of the population. The limited availability of preventive and therapeutic procedures and the low effectiveness of health promotion programs mean that oral health problems progress to a point where more complex care is required, often culminating in a need for referral to the secondary level of care.

One way of identifying the actual demand, utilization patterns, and which locations are most lacking in oral health care services is to conduct nationwide population-based surveys. Such sur- veys involve a representative sample of the population and, consequently, provide a more reliable portrait of the reality of health care services and their users.

Within this context, the purpose of the present study was to describe and compare data obtained from the 1998, 2003, and 2008 National Household Sample Services (PNAD) on access to and utilization of dental care services by Brazilian children aged 4 to 12 years.

\section{Methods}

This was a quantitative, exploratory, cross-sectional study using data from the 1998, 2003, and 2008 PNADs. These nationwide surveys, conducted by the Brazilian Institute of Geography and Statistics (IBGE), assesses several characteristics of Brazilian households ${ }^{10}$.

In 1998, the five-yearly PNADs were expanded to include questions on access to and utilization of oral health care services. These questions include: time since last dentist visit; search for dental care in the last 2 weeks; access to dental care services and characterization of payment for such services; use of dental insurance; type of facility where care was provided; and evaluation of the service provided. In the first year, the PNAD sample comprised 344,945 individuals, and was conducted in the cities of Belém, Fortaleza, Recife, Salvador, Belo Horizonte, Rio de Janeiro, São Paulo, Curitiba, and Porto Alegre. The reference date for data collection was September 26, 1998, and the reference week, September 20-26, $1998^{11}$.

For the 2003 PNAD, 384,834 respondents from 851 municipalities across different states and nine metropolitan regions (Belém, Fortaleza, Recife, Salvador, Belo Horizonte, Rio de Janeiro, São Paulo, Curitiba, and Porto Alegre) were interviewed. This survey had a reference period of 365 days, from September 28, 2002 to September 27, $2003^{12}$.

The 2008 PNAD kept the items on access to and utilization of health services and was further expanded to include data on household registration for the Family Health Program. For this survey, 391,868 individuals from 150,591 households across every state in the country were interviewed. Interviews were conducted from September 28, 2007 through September 28, $2008^{13}$.

Our study sample, composed of children aged 4 to 12 years who were included in the 1998,2003 , and 2008 PNADs, was thus extracted from this contingent of respondents. The constraint on age 
range was defined because many parafunctional habits, dental caries, maxillomandibular abnormalities, and respiratory and nutritional conditions develop during this stage of child development ${ }^{14,15}$. Furthermore, from the age of 6 , children enter the mixed dentition stage, which is characterized by an increase in number of dental surfaces and, often, the use of orthodontic appliances, which make access to dental care of the utmost importance for obtaining or maintaining acceptable levels of oral health.

The structure of PNADs provides for two levels of information. The first covers household-level data, while the second consists of information on the residents of each household. Since 1998, these surveys have included a health supplement that contains several modules of health-related items, from morbidity to limitation s to physical activities in children over age $13^{11}$. However, the present study was restricted to items of specific interest to oral health, such as access to dental services, utilization of these services, and out-ofpocket spending on oral health.

The dependent variable was dental visit attendance, measured by the item "When did (...) last go to the dentist?". The 1998, 2003, and 2008 PNAD questionnaires included five possible answers to the item "When did (...) last go to the dentist?", namely: (1) "less than1 year ago"; (2) "1 year to less than 2 years ago"; (3) "2 years to less than 3 years ago"; (4) " 3 or more years ago"; and (5) "never".

The independent variables related to children's sociodemographic characteristics were sex (male or female); age $(4,5,6,7,8,9,10,11$, or 12 years); skin color (White/Yellow or Black/ Brown/Indigenous Brazilian); household income bracket, stratified into quartiles (1st, $2 \mathrm{nd}$, 3rd, or 4 th quartile); educational level of the head of the household ( 0 to 4,5 to 8 , or 9 or more years of schooling); region of Brazil (North, Northeast, Southeast, South, or Center-West); and housing situation (urban or rural).

For children who had sought medical attention in the two weeks preceding the interview, variables were collected regarding the reason for seeking care (dental problem or other), and, only for those who had sought dental care specifically, where such care had been sought (primary health center, dental clinic, or other - physician's offices, urgent care or emergency departments, hospitals, outpatient clinics, or onsite clinics at companies or trade unions).

Statistical analyses were performed in the Stata version 10 software environment (StataCorp
LP., College Station, Tex., USA), taking into account the sample design of the PNADs, i.e., specifying the weight, strata, and primary sampling units (PSUs) as reported by IBGE. Ninety-nine percent confidence intervals (99\%CIs) were considered for the prevalence coefficients of all outcomes of interest. Statistical significance was analyzed by these intervals at the $1 \%$ level.

This study was performed using data from secondary sources (PNADs). As the databases made available by IBGE do not allow identification of survey subjects, anonymity was ensured by design. Finally, all IBGE surveys, including the PNADs, are conducted for means of public policy-making and comply with all internationally ethical principles for human subject research.

\section{Results}

Table 1 presents data on socioeconomic characteristics for children included in the 1998 (n $=61,438), 2003(\mathrm{n}=64,659)$, and 2008 ( $\mathrm{n}=$ 59,561) PNADs. The frequency distributions of sex and age were similar across all years. Regarding skin color, there was a slight increase in the number of Black/Brown/Indigenous Brazilian respondents, from $53.5 \%$ in 1998 to $58.7 \%$ in 2008. The percentage of children from families with a monthly household income in the 1 st quartile also increased over time, from $37.6 \%$ in 1998 to $41.3 \%$ in 2003 and $43.5 \%$ in 2008 . Conversely, the number of children from families in which the head of household had an educational level of 4 years or less declined over time (53\% in $1998,45.9 \%$ in 2003 , and $38.2 \%$ in 2008). In all three PNADs, children from the Northeast and Southeast regions predominated over those from other regions, as did children from urban areas as compared with rural areas.

In 1998, the lifetime prevalence of a dental visit among Brazilian children aged 4 to 12 years (Table 2) was 60.8\% (99\%CI: 59.4;62.1). In 2003, this figure had risen to $65.6 \%$ (99\%CI: 64.4;66.7), and in 2008 , to $73.8 \%$ (99\%CI: 72.1;74.2).

Furthermore, as the age of children advanced, so did the number of children who had ever seen a dentist increase, across all three years. For instance, in 1998, 29.5\% (99\%CI: 27.5;31.5) of 4-year-olds in the sample had ever seen a dentist, versus $77.3 \%$ (99\%CI: 75.4;79.1) of 12-yearolds. A similar phenomenon was observed in 2008: 43.9\% (99\%CI: 41.6;46.1) of 4-year-olds had seen a dentist, versus $86.8 \%$ of 12 -year-olds (99\%CI: 85.2;88.3). Regarding the skin color 
Table 1. Absolute and relative frequency (\%) of variables related to socioeconomic status among (age 4-12 years) included in the sample. Brazil, 1998, 2003 and 2008.

\begin{tabular}{|c|c|c|c|c|c|c|}
\hline \multirow[b]{2}{*}{ Variable } & \multicolumn{2}{|c|}{1998 PNAD } & \multicolumn{2}{|c|}{2003 PNAD } & \multicolumn{2}{|c|}{2008 PNAD } \\
\hline & $\mathbf{n}$ & $\begin{array}{l}\text { Frequency } \\
(\%)\end{array}$ & $\mathbf{n}$ & $\begin{array}{l}\text { Frequency } \\
(\%)\end{array}$ & $\mathbf{n}$ & $\begin{array}{l}\text { Frequency } \\
\quad(\%)\end{array}$ \\
\hline \multicolumn{7}{|l|}{ Sex } \\
\hline Male & 31,287 & 50.9 & 32,855 & 50.8 & 30,450 & 51.1 \\
\hline Female & 30,151 & 49.1 & 31,804 & 49.2 & 29,111 & 48.9 \\
\hline \multicolumn{7}{|l|}{ Age (years) } \\
\hline 4 & 6,658 & 10.8 & 7,088 & 11 & 5,965 & 10 \\
\hline 5 & 6,581 & 10.7 & 7,077 & 10.9 & 5,925 & 9.9 \\
\hline 6 & 6,599 & 10.7 & 7,129 & 11 & 6,117 & 10.3 \\
\hline 7 & 6,573 & 10.7 & 7,313 & 11.3 & 6,338 & 10.6 \\
\hline 8 & 6,649 & 10.9 & 7,406 & 11.5 & 6,929 & 11.6 \\
\hline 9 & 6,861 & 11.2 & 7,308 & 11.3 & 7,057 & 11.9 \\
\hline 10 & 7,251 & 11.8 & 7,186 & 11.1 & 7,014 & 11.8 \\
\hline 11 & 6,997 & 11.4 & 7,149 & 11.1 & 7,010 & 11.8 \\
\hline 12 & 7,269 & 11.8 & 7,003 & 10.8 & 7,206 & 12.1 \\
\hline \multicolumn{7}{|l|}{ Skin color } \\
\hline White or Yellow & 28,593 & 46.5 & 28,235 & 43.7 & 24,569 & 41.3 \\
\hline $\begin{array}{l}\text { Black, Brown, or Indigenous } \\
\text { Brazilian }\end{array}$ & 32,840 & 53.5 & 36,422 & 56.3 & 4,938 & 58.7 \\
\hline \multicolumn{7}{|l|}{$\begin{array}{l}\text { Monthly household income } \\
\text { bracket (quartiles) }\end{array}$} \\
\hline 1st quartile & 23,089 & 37.6 & 26,730 & 41.3 & 25,921 & 43.5 \\
\hline 2nd quartile & 17,167 & 27.9 & 18,178 & 28.1 & 16,542 & 27.8 \\
\hline 3rd quartile & 11,793 & 19.2 & 11,424 & 17.7 & 9,854 & 16.5 \\
\hline 4th quartile & 9,389 & 15.3 & 8,327 & 12.9 & 7,244 & 12.2 \\
\hline \multicolumn{7}{|l|}{$\begin{array}{l}\text { Educational level of head of } \\
\text { household (years of formal }\end{array}$} \\
\hline 0 to 4 & 15,613 & 25.5 & 18,139 & 28.3 & 16,274 & 27.5 \\
\hline 5 to 8 & 13,164 & 21.5 & 16,561 & 25.8 & 20,349 & 34.3 \\
\hline 9 or more & & & & & & \\
\hline \multicolumn{7}{|l|}{ Region of Brazil } \\
\hline North & 5,399 & 8.8 & 8,407 & 13 & 9,696 & 16.3 \\
\hline Northeast & 21,395 & 34.8 & 22,743 & 35.2 & 20,333 & 34.1 \\
\hline Southeast & 18,488 & 30.1 & 17,043 & 26.3 & 15,106 & 25.4 \\
\hline South & 9,543 & 15.5 & 9,311 & 14.4 & 7,834 & 13.1 \\
\hline Center-West & 6,613 & 10.8 & 7,155 & 11.1 & 6,592 & 11.1 \\
\hline \multicolumn{7}{|l|}{ Household situation } \\
\hline Urban & 48,303 & 78.6 & 54,076 & 83.6 & 48,360 & 81.2 \\
\hline Rural & 13,135 & 21.4 & 10,583 & 16.4 & 11,201 & 18.8 \\
\hline
\end{tabular}

Source: Own work after microdata from the National Household Sample Surveys (Pesquisa Nacional por Amostra de Domicílios, PNAD) conducted by the Brazilian Institute of Geography and Statistics (IBGE) in 1998, 2003, and 2008.

variable, White/Yellow respondents were more likely to have attended dental visits than Black/ Brown/Indigenous Brazilian children. The difference was $18.8 \%$ in $1998,15.3 \%$ in 2003 , and $11.2 \%$ in 2008 , which demonstrates that this racial difference decreased over time.
Analysis of household income data stratified by quartile revealed that, the higher the family income, the larger the number of children who had ever received dental care. However, the number of children from families in the 1st income quartile who had seen a dentist increased progres- 
Table 2. Lifetime prevalence (\%) of dental visit in children aged 4-12 years, stratified by sociodemographic variables. Brazil, 1998, 2003 and 2008.

\begin{tabular}{|c|c|c|c|c|c|c|}
\hline \multirow[b]{2}{*}{ Variable } & \multicolumn{2}{|c|}{1998 PNAD } & \multicolumn{2}{|c|}{2003 PNAD } & \multicolumn{2}{|c|}{2008 PNAD } \\
\hline & $\begin{array}{l}\text { Prevalence } \\
(\%)\end{array}$ & $99 \% \mathrm{CI}^{*}$ & $\begin{array}{l}\text { Prevalence } \\
\quad(\%)\end{array}$ & $99 \% \mathrm{CI}^{*}$ & $\begin{array}{l}\text { Prevalence } \\
\quad(\%)\end{array}$ & $99 \% \mathrm{CI}^{*}$ \\
\hline \multicolumn{7}{|l|}{ Sex } \\
\hline Male & 60.1 & $58.6 ; 61.5$ & 65.1 & $63.9 ; 66.4$ & 72.7 & $71.4 ; 73.9$ \\
\hline Female & 61.5 & $60 ; 63$ & 66 & $64.7 ; 67.3$ & 73.7 & $72.4 ; 74.9$ \\
\hline \multicolumn{7}{|l|}{ Age (years) } \\
\hline 4 & 29.5 & $27.5 ; 31.5$ & 34.8 & $32.8 ; 36.9$ & 43.9 & $41.6 ; 46.1$ \\
\hline 5 & 40.1 & $38 ; 42.3$ & 47.3 & $45.3 ; 49.3$ & 53.5 & $51.3 ; 55.7$ \\
\hline 6 & 48.2 & $45.9 ; 50.5$ & 57.3 & $55.2 ; 59.4$ & 64 & $61.8 ; 66.1$ \\
\hline 7 & 60.3 & $58 ; 62.5$ & 65.1 & $63.1 ; 67.1$ & 71.8 & $69.7 ; 73.7$ \\
\hline 8 & 65.4 & $63.2 ; 67.6$ & 70 & $68 ; 71.9$ & 76.7 & $74.8 ; 78.5$ \\
\hline 9 & 70.8 & $68.6 ; 72.9$ & 75 & $73 ; 77$ & 81.5 & $79.7 ; 83.1$ \\
\hline 10 & 74.3 & $72.1 ; 76.3$ & 78.1 & $76.3 ; 79.9$ & 85.2 & $83.6 ; 86.7$ \\
\hline 11 & 76 & $74.1 ; 77.8$ & 80.3 & $78.5 ; 81.9$ & 85.7 & $84.2 ; 87.1$ \\
\hline 12 & 77.3 & $75.4 ; 79.1$ & 81.5 & $79.9 ; 83.1$ & 86.8 & $85.2 ; 88.3$ \\
\hline \multicolumn{7}{|l|}{ Skin color } \\
\hline White or Yellow & 70.3 & $68.9 ; 71.7$ & 73.6 & $72.3 ; 74.8$ & 79.4 & $78.3 ; 80.4$ \\
\hline $\begin{array}{l}\text { Black, Brown, or Indigenous } \\
\text { Brazilian }\end{array}$ & 51.5 & $49.6 ; 53.5$ & 58.3 & $56.7 ; 59.9$ & 68.2 & $66.8 ; 69.7$ \\
\hline \multicolumn{7}{|c|}{$\begin{array}{l}\text { Monthly household income bracket } \\
\text { (quartiles) }\end{array}$} \\
\hline 1st quartile & 41.2 & $39.1 ; 43.3$ & 49.9 & $48 ; 51.9$ & 61.4 & $59.5 ; 63.2$ \\
\hline 2nd quartile & 62.4 & $60.6 ; 64.1$ & 67.5 & $66.1 ; 68.9$ & 76.3 & $74.9 ; 77.5$ \\
\hline 3rd quartile & 76 & $74.5 ; 77.5$ & 79.4 & $78 ; 80.7$ & 84.2 & $82.8 ; 85.4$ \\
\hline 4th quartile & 86.4 & $84.9 ; 87.7$ & 88.9 & $87.7 ; 90.1$ & 90.4 & $89.1 ; 91.5$ \\
\hline \multicolumn{7}{|c|}{$\begin{array}{l}\text { Educational level of head of household } \\
\text { (years of formal education) }\end{array}$} \\
\hline 0 to 4 & 49.5 & $47.7 ; 51.3$ & 54.2 & $52.2 ; 56.1$ & 63 & $61.1 ; 64.9$ \\
\hline 5 to 8 & 67.2 & $65.5 ; 68.8$ & 69.5 & $68.1 ; 70.9$ & 74.3 & $72.9 ; 75.7$ \\
\hline 9 or more & 82.8 & $81.4 ; 84.1$ & 82.1 & $80.9 ; 83.2$ & 83.9 & $82.8 ; 84.8$ \\
\hline \multicolumn{7}{|l|}{ Region of Brazil } \\
\hline North & 58.8 & $54.4 ; 63.1$ & 60.7 & $56.8 ; 64.4$ & 65.2 & $62.1 ; 68.1$ \\
\hline Northeast & 43.7 & $41 ; 46.5$ & 49.1 & $46.6 ; 51.7$ & 62.1 & $59.7 ; 64.5$ \\
\hline Southeast & 70.2 & $68.6 ; 71.7$ & 74.6 & $72.9 ; 76.1$ & 79.8 & $78.4 ; 81.1$ \\
\hline South & 71.9 & $68.8 ; 74.9$ & 77.6 & $75.4 ; 79.7$ & 84.2 & $82.1 ; 86.1$ \\
\hline Center-West & 66.8 & $64.2 ; 69.3$ & 72.4 & $69.8 ; 74.8$ & 79 & $76.3 ; 81.5$ \\
\hline \multicolumn{7}{|l|}{ Household situation } \\
\hline Urban & 67.2 & $65.9 ; 68.4$ & 70.1 & $69.1 ; 71.1$ & 76.9 & $76 ; 77.9$ \\
\hline Rural & 40.5 & $37.5 ; 43.6$ & 45.3 & $41.6 ; 48.9$ & 57.6 & $54.3 ; 60.8$ \\
\hline Total & 60.8 & $59.4 ; 62.1$ & 65.6 & $64.4 ; 66.7$ & 73.2 & $72.1 ; 74.2$ \\
\hline
\end{tabular}

${ }^{*} 99 \%$ confidence interval

Source: Own work after microdata from the National Household Sample Surveys (Pesquisa Nacional por Amostra de Domicílios, PNAD) conducted by the Brazilian Institute of Geography and Statistics (IBGE) in 1998, 2003, and 2008.

sively, from $41.2 \%$ in 1998 (99\%CI: $39.1 ; 43.3$ ) to $49.9 \%$ in 2003 (99\%CI: $48 ; 51.9)$; to $61.4 \%$ in 2008 (99\%CI: 59.5;63.2).

Regarding educational level, in 1998, of children whose head-of-household had had 4 years of formal education or less, $49.5 \%$ (99\%CI: 47.7;51.3) had ever seen a dentist, versus 54.2\% in 2003 (99\%CI: $52.2 ; 56.1)$ and $63 \%$ in 2008 (99\%CI: 61.1;64.9).

The percentage of individuals in their respective age ranges who had ever seen a dentist increased in all regions of Brazil. However, the South region had the highest proportion of children who had received dental care across all 3 
years, with a rate of $71.9 \%$ (99\%CI: $68.8 ; 74.9)$ in $1998,77.6 \%$ (99\%CI: 75.4;79.7) in 2003, and $84.2 \%$ (99\%CI: 82.1;86.1) in 2008. The Northeast region had the lowest proportions of children who had ever seen a dentist: $43.7 \%$ (99\%CI: 41;46.5), $49.1 \%$ (99\%CI: $46.6 ; 51.7$ ), and $62.1 \%$ (99\%CI: 59.7;64.5) in 1998, 2003, and 2008 respectively.

Regarding housing situation, children living in rural zones were less likely to ever have received dental care than children living in urban areas. However, this proportion improved $17.1 \%$ over the 10 -year study period, from $40.5 \%$ (99\%CI: $37.5 ; 43.6)$ in 1998 to $45.3 \%$ (99\%CI: $41.6 ; 48.9$ ) in 2003 and $57.6 \%$ (99\%CI: 54.3;60.8) in 2008.

Analysis of the search for medical attention in the 2 weeks preceding the interview revealed that, in 1998 , of the 61,438 children included in the survey, 9.1\% (99\%CI: 8.5;9.6) had sought care, of whom $16.6 \%$ (99\%CI: $14.6 ; 18.5)$ had done so for a dental problem. Among children who had sought dental care services, $67.3 \%$ (99\%CI: $60.6 ; 74)$ had done so at a dentist's office, $20.4 \%$ (99\%CI: $14.6 ; 26.2)$ at a primary health center, and $12.3 \%(99 \%$ CI: $7.7 ; 17)$ at other facilities, including physician's offices, urgent care or emergency departments, hospitals, outpatient clinics, or onsite clinics at companies or trade unions.

In 2003, of the 64,659 children surveyed, 6,853 had been taken to seek care at a health facility, which corresponds to $10.7 \%$ (99\%CI: $10.2 ; 11.3)$ of the sample. Of these, $11.8 \%$ (99\%CI: 10.4;13.2) had sought care for a dental problem. Of these, $62.9 \%$ (99\%CI: 56;69.7) had been taken to a dentist's office, $27.7 \%$ (99\%CI: $21.7 ; 36.9$ ) to a primary health center, and $9.4 \%$ (99\%CI: 5.5;13.3) to other facilities.

In 2008 , of the 59,561 children surveyed, 3,742 (13.3\%, 99\%CI: 12.5;14.0) had been taken to seek medical attention; of these, $29 \%$ (99\%CI: $26.5 ; 31.4$ ) had done so for a dental problem. Of these, $57.5 \%$ (99\%CI: 52.1;62.8) had sought care at a dentist's office, $33.8 \%$ (99\%CI: $28.5 ; 39.0)$ at a primary health center, and $8.8 \%(99 \% \mathrm{CI}$ : $5.9 ; 11.7)$ at other facilities.

\section{Discussion}

The $13 \%$ increase in access to and utilization of dental care services by children in the 4-to- 12 age range, demonstrated by the results of the present study, may be considered one of the driving factors behind the reduction of pediatric DMFT indices in Brazil, from 2.8 in 2003 to 2.1 in 2010 (in 12-year-old schoolchildren), and the increase in prevalence of caries-free children ${ }^{7,16}$. Possibly, these findings also may have been influenced by policies implemented through the Brazilian Unified Health System (SUS), such as the incorporation of oral health into the Family Health Strategy and the establishment of the "Smiling Brazil" Program (Programa Brasil Sorridente) (,17 $^{6}$.

According to data from the 2008 PNAD, approximately $26 \%$ of survey respondents had never visited a dentist in their lives. Other studies conducted in different regions of Brazil have reported similar situations. A study of 350 children aged 0 to 14 years conducted in the municipality of Ponta Grossa, state of Paraná, found that 31\% of participants had never been to a dentist ${ }^{2}$. In the municipality of Canela, state of Rio Grande do Sul, only $13.3 \%$ of a sample of 1,092 children aged 0 to 5 had ever attended a dental visit ${ }^{18}$. Another study of 997 children (all aged 5) in the city of Montes Claros, state of Minas Gerais, found that $64.3 \%$ had never visited a dentist. This prevalence was lower in children covered by the Family Health Strategies, one of the core principles of which is the search for comprehensive, multidisciplinary care of every family unit ${ }^{19}$.

Despite evident progress in oral health indicators in Brazil, a substantial portion of the population still does not utilize such services to the fullest extent ${ }^{7,20,21}$. This challenge, which may be caused by absence of coverage in areas with poor social and economic indicators, by barriers to access, and by a lack of educational and preventive interventions, means that oral conditions often worsen to the extent that, e.g., minor caries might progress to the point of requiring invasive and even mutilating treatment ${ }^{1}$.

Another factor associated with progression of oral conditions is that younger children visited the dentist less often than older children did, as shown by a comparison of the 3 years surveyed in the present study. The natural history of dental caries when left untreated, whether because of barriers to access to oral health services or due to failure to include children in education and prevention programs, may lead to a delayed search for care, with children presenting only when the condition has become painful. An assessment conducted by the Health Needs Index in the Brazilian state of São Paulo found that 12-year-old schoolchildren had less access to dental services than 15 -year-olds, and that $7.3 \%$ required mutilating interventions ${ }^{1}$.

In the United States, all children receive preventive interventions, but younger ones and 
those with worse oral health status receive more such procedures than older children $\mathrm{do}^{22}$. This is reflected by fewer curative treatments in future and, consequently, lower government expenditures on curative interventions.

Dental visits become more frequent as family income and educational attainment increase, as shown in the present study, although there was a $20 \%$ increase in dental services utilization by preschoolers and schoolchildren from lower-income (1st-quartile) families between 1998 and 2008. Similar results were found in a study conducted in Ponta Grossa, state of Paraná, which evaluated factors implicated in access to oral health services in a sample of 774 participants; those with a higher monthly family income had attended more dental visits in the preceding year ${ }^{23}$.

Access to public services by people from low-income, low-education families has been increasing, as a result of greater investment in financial and human resources and implementation of public health policies that prioritize population oral health in previously underserved areas, with a focus not only on curative treatment but also on educational and preventive aspects ${ }^{4,6,7,9}$

In a previous study, worse DMFT (decayed-missing-filled teeth) indices were significantly associated with a maternal educational attainment of 8 years or less ${ }^{24}$. Furthermore, mothers and guardians who have a regular source of dental care report better oral health, less odontogenic pain, a higher frequency of dental visits, and a higher frequency of oral hygiene in their children as compared with mothers who do not attend dental visits ${ }^{25}$. These findings corroborate the fact that children's oral health conditions are directly influenced by the habits of their parents, which, in turn, are related to educational level ${ }^{19}$.

Caries and odontogenic pain are susceptible to socioeconomic and geographical inequalities. In a study that evaluated toothache in 7,280 school-aged children (age 5) from several regions in Brazil, the overall prevalence was $22 \%$. However, this rate was markedly higher in children living in low-HDI municipalities, those in populations with low educational attainment $(<8$ years of schooling), and from low-income families ${ }^{26}$. Another study conducted in children aged 8 to 12 found that a poor school environment was positively associated with dental caries ${ }^{24}$.

The present study found that the majority of participants who had received dental care were in the South and Southeast regions of Brazil and living in urban areas, which is consistent with the results of the 2010 SB Brasil nationwide oral health survey. In this survey, conducted in 177 municipalities across Brazil, the highest deft indices were found in the North (2.93) and Center-West (2.69) regions of the country ${ }^{7}$. Nevertheless, since 2008, the distribution of public oral health care services appears to have improved as a consequence of the national oral health policy, which is based on increasing service delivery at the primary care level and implementing facilities known as Dental Specialty Centers (Centros de Especialidades Odontológicas) to establish an infrastructure for secondary care. Data from the SB Brasil survey reflect this new reality, with a $46 \%$ nationwide prevalence of children with no dental caries at age 5 years and particularly noteworthy rates in the Northeast and Southeast regions (41\% and 51\% respectively) ${ }^{7}$.

Analysis of results regarding the search for oral health care in the 2 weeks preceding the PNAD survey interview revealed that most children were taken to private dentist's offices. Conversely, in a study conducted in the state of Maranhão, of 1,214 children under 5 in the sample, only 105 had received dental care in the 6 months preceding the study, with most $(61.2 \%)$ taken to UHS facilities ${ }^{27}$. According to the 2013 National Health Survey (Pesquisa Nacional de Saúde, PNS), most participants aged 12 received care through the publicly funded health system, followed by private facilities ${ }^{9}$. The growing search for public oral health care services may reflect an increased availability of these services in previously underserved areas, thus facilitating access in regions where private dental practices were once the only option for care.

As the PNAD interviews are conducted using structured questionnaires, it is important to note that the collected data are actually provided by the children's parents or guardians. Therefore, the results may have been subject to reporting bias. Another limitation of this study was its cross-sectional design, which precluded any inferences as to causal relationships, although the variable educational level - unlike income tends to remain stable during the life course and is unaffected by morbidity and disabilities occurring in adulthood.

Finally, scaling up collective and primary care-based oral health interventions by means of the Family Health Strategies has enabled the adoption of a more proactive stance toward oral health care. The availability of Dental Specialty Centers for referral from primary care has also expanded the offer of oral health care. It bears stressing that public health dentistry should not 
be limited to clinical attention, but rather include community interventions, conduction of epidemiological surveys, preventive actions, and health education initiatives ${ }^{6}$.

\section{Conclusion}

Despite significant efforts by the Brazilian government to implement universal access to oral health in the primary care setting and address limitations and obstacles to comprehensiveness, some weaknesses are still apparent. Until the core principle of universal care is fully achieved, public policy-makers should focus their efforts on regional differences within the country, taking into account the socioeconomic and demographic characteristics, needs, and peculiarities of each region. Surveys such as the PNADs play an essential role on identifying which populations most lack dental care services, thus helping managers address planning, efficiency, and efficacy issues with the country's actual needs in mind.

\section{Collaborations}

JC Barasuol, LP Garcia, RC Freitas, DM Dalpian, JVNB Menezes and BZ Santos contributed, read and approved this manuscript. 


\section{Referências}

1. Junqueira SR, Frias CA, Zilbovicius C, Araujo ME. Saúde bucal e uso dos serviços odontológicos em função do Índice de Necessidades em Saúde: São Paulo, 2008. Cien Saude Colet 2012; 17(4):1015-1024.

2. Baldani MH, Mendes YBE, Lawder JAC, Lara API, Rodrigues MMAS, Antunes JLF. Inequalities in dental services utilization among Brazilian low-income children: the role of individual determinants. J Public Health Dent 2011; 71(1):46-53.

3. Ulinski SLV, Aguilera B, França HS, Moysés ST, Moysés SJ. Articulação entre os níveis de atenção dos serviços de saúde na Região Metropolitana de Curitiba: desafios para os gestores. Rev. Adm. Pública 2013; 47(4):10211039.

4. Aquilante AC, Aciole GG. Construindo um "Brasil Sorridente"? Olhares sobre a implementação da Política Nacional de Saúde Bucal numa região de saúde do interior paulista. Cad Saude Publica 2015; 31(1):82-96.

5. Peres KG, Peres MA, Boing AF, Bertoldi AD, Bastos JL, Barros AJD. Reduction of social inequalities in utilization of dental care in Brazil from 1998 to 2008. Rev Saude Publica 2012; 46(2):250-258.

6. Pucca Júnior GA, Gabriel M, Araujo ME, Almeida FCS Ten Years of a National Oral Health Policy in Brazil: Innovation, Boldness, and Numerous Challenges. J Dent Res 2015; 94(10):1333-1337.

7. Brasil. Ministério da Saúde (MS). Projeto SB Brasil. Pesquisa Nacional de Saúde Bucal - Resultados Principais. Brasília: MS; 2012.

8. Programa das Nações Unidas para o Desenvolvimento (PNUD). Ranking IDHM Unidades da Federação 2010. [acessado 2015 Dez 2]. Disponível em: http://www. atlasbrasil.org.br/2013/pt/ranking/

9. Instituto Brasileiro de Geografia e Estatística (IBGE). Pesquisa Nacional de Saúde/ Acesso e Utilização dos Serviços de Saúde 2013. Rio de Janeiro: IBGE; 2015.

10. Instituto Brasileiro de Geografia e Estatística (IBGE). Pesquisa Nacional por Amostra de Domicílios. [acessado 2015 Dez 2]. Disponível em: http://www.ibge.gov. $\mathrm{br} /$ home/estatistica/pesquisas/pesquisa_resultados. php?id_pesquisa $=40$

11. Instituto Brasileiro de Geografia e Estatística (IBGE). Pesquisa Nacional por Amostra de Domicílios 1998. Rio de Janeiro: IBGE; 1998. [acessado 2015 Dez 2]. Disponível em: http://www.ibge.gov.br/home/estatistica/ populacao/trabalhoerendimento/pnad98/saude/saude. pdf

12. Instituto Brasileiro de Geografia e Estatística (IBGE). Pesquisa Nacional por Amostra de Domicílios, 2003. Rio de Janeiro: IBGE; 2003. [acessado 2015 Dez 2]. Disponível em: http://www.ibge.gov.br/home/estatistica/ populacao/trabalhoerendimento/pnad2003/brasilpnad2003.pdf

13. Instituto Brasileiro de Geografia e Estatística (IBGE). Pesquisa Nacional por Amostra de Domicílios 2008. Rio de Janeiro: IBGE; 2008. [acessado 2015 Dez 2]. Disponível em: http://www.ibge.gov.br/home/estatistica/ populacao/trabalhoerendimento/pnad2008/brasilpnad2008.pdf

14. Firmino RT, Gomes MC, Clementino MA, Martins CC, Paiva SM, Granville-Garcia AF. Impact of oral health problems on the quality of life of preschool children: a case-control study. Int J Paediatr Dent 2016; 26(4):242-249.
15. Oliveira MT, Bittencourt ST, Marcon K, Destro S, Pereira JR. Sleep bruxism and anxiety level in children. Braz Oral Res 2015; 29(1):1-5.

16. Roncalli AG, Sheiham A, Tsakos G, Watt RG. Socially unequal improvements in dental caries levels in Brazilian adolescents between 2003 and 2010. Community Dent Oral Epidemiol 2015; 43(4):317-324.

17. Antunes JLF, Narvai PC. Políticas de saúde bucal no Brasil e seu impacto sobre as desigualdades em saúde. Rev Saude Publica 2010; 44(2):360-365.

18. Kramer PF, Ardenghi TM, Ferreira S, Fischer LA, Cardoso L, Feldens CA. Utilização de serviços odontológicos por crianças de 0 a 5 anos de idade no Município de Canela, Rio Grande do Sul, Brasil. Cad Saude Publica 2008; 24(1):150-156.

19. Palma ABO, Ferreira RC, Martins AMEB, Assis KBO, Duarte DA. Determinantes do não uso de serviços odontológico por crianças de cinco anos. Arq Odontol 2015; 51(1):14-24.

20. Aguilera SLVU, França BHS, Moysés ST, Moysés SJ. Iniquidades intermunicipais no acesso e utilização dos serviços de atenção secundária em saúde na região metropolitana de Curitiba. Rev Bras Epidemiol 2014; 17(3):654-666.

21. Soares FF, Chaves SCL, Cangussu MCT. Governo local e serviços odontológicos: análise da desigualdade na utilização. Cad Saude Publica 2015; 31(3):586-596.

22. Bell JF, Huebner CE, Reed SC. Oral health need and access to dental services: evidence from the national survey of children's health, 2007. Matern Child Health J 2012; 16(Supl. 1):27-34

23. Baldani $M$, Antunes JLFS. Inequalities in access and utilization of dental services: a cross-sectional study in an area covered by the Family Health Strategy. Cad Saude Publica 2011; 27(2):272-283.

24. Fernández MR, Goettems ML, Ardenghi TM, Demarco FF, Correa MB. The role of school social environment on dental caries experience in 8- to 12 -year-old brazilian children: a multilevel analysis. Caries Res 2015; 49(5):548-556.

25. Grembowski D, Spiekerman C, Milgrom P. Linking mother access to dental care and child oral health. Community Dent Oral Epidemiol 2009; 37(5):381-390.

26. Ferreira-Junior OM, Freire MCM, Moreira RS, Costa LR. Contextual and individual determinants of dental pain in preschool children. Community Dent Oral Epidemiol 2015; 43(4):349-356.

27. Gomes AMM, Thomaz EBAF, Alves MTSSB, Silva AAM, Silva RA. Fatores associados ao uso dos serviços de saúde bucal: estudo de base populacional em municípios do Maranhão, Brasil. Cien Saude Colet 2014; 19(2):629-640.

Artigo apresentado em 12/10/2016

Aprovado em 20/03/2017

Versão final apresentada em 22/03/2017 